\title{
Evaluation of Patients Diagnosed as Having Acute Stroke in the Emergency Department: Two-year Analysis
} Acil Serviste Akut İnme Tanısı Alan Hastaların Değerlendirilmesi: İki Yıllık Analiz

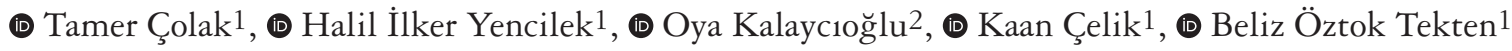 \\ ${ }^{1}$ Bolu Abant İzzet Baysal University Medical Faculty Training and Research Hospital, Clinic of Emergency, Bolu, Turkey
}

2Bolu Abant Izzet Baysal University Faculty of Economics and Administrative Sciences, Department of Econometrics of Administrative, Bolu, Turkey

\begin{abstract}
Objective: To investigate the etiologic, demographic, and clinical features of patients who were diagnosed as having acute stroke in the emergency department and thus, we aimed to contribute to the stroke data of our country, primarily to the data of our region.

Materials and Methods: This study was retrospectively conducted on the data of 236 patients who were diagnosed as having acute stroke and admitted to the emergency department between January 1st 2017 , and December 31st 2018.

Results: Of the patients, $210(88.9 \%)$ were diagnosed as having ischemic stroke and 26 were diagnosed as having hemorrhagic stroke (11.1\%). One hundred six (44.9\%) of the patients were admitted to the hospital within the first 4.5 hours, 130 (55.1\%) - arrived to the hospital after 4.5 hours. Two hundred five (86.9\%) patients were discharged from the hospital, and $31(13.1 \%)$ patients died. Hypertension was found to be the most common risk factor among patients, followed by smoking. The highest number of patients was admitted during summer with a rate of $29.7 \%$. Atrial fibrillation was found to be an independent risk factor of mortality in patients with acute stroke and increased the odds of mortality by 3.18 ( $\mathrm{p}=0.008)$.
\end{abstract}

Conclusion: Although our study reflects a large part of the stroke data of the Bolu province, it gives valuable results for the Western Black Sea region.

Keywords: Bolu, stroke, emergency department

\section{Öz}

Amaç: Çalışmamızda, acil serviste akut inme tanısı alan hastaların etiyolojik, demografik ve klinik özelliklerini araştırmayı ve bu sayede öncelikle bölgemiz verileri olmak üzere ülkemizin inme verilerine katkıda bulunmayı amaçladık.

Gereç ve Yöntem: Çalışma, 01.01.2017-31.12.2018 tarihleri arasında acil servise başvuran ve inme tanısı alan toplam 236 hastanın verileri üzerinden retrospektif olarak yapildı.

Bulgular: Hastaların 210'u (\%88,9) iskemik inme ve 26 'sı hemorajik inme $(\% 11,1)$ tanısı aldı. Yüz altı $(\% 44,9)$ hasta ilk 4,5 saat içerisinde başvururken, 130 $(\% 55,1)$ hasta 4,5 saatin üzerindeki bir süre de başvurdu. İki yüz beş $(\% 86,9)$ hasta hastaneden taburcu edilirken, $31(\% 13,1)$ hasta öldü. Hastalarda hipertansiyon en sık tespit edilen risk faktörü iken, ikinci sıklıkta sigara kullanımının olduğu görüldü. En sık hasta başvurusunun \%29,7 oranıyla yaz aylarında olduğu görüldü. Atriyal fibrilasyon akut inmeli hastalarda mortalite için bağımsız bir risk faktörü olarak belirlendi ve atriyal fibrilasyonun mortalite riskini 3,18 kat artırdığ görüldü ( $\mathrm{p}=0,008)$.

Sonuç: Çalışmamız Bolu ilinin inme verilerinin büyük bir kısmını yansıtmakla beraber, Batı Karadeniz Bölgesi açısından kıymetli sonuçlar vermiştir. Anahtar Kelimeler: Bolu, inme, acil servis

Address for Correspondence/Yazışma Adresi: Tamer Çolak MD, Bolu Abant İzzet Baysal University Medical Faculty Training and Research Hospital, Clinic of Emergency, Bolu, Turkey

Phone: +90 5075009092 E-mail: drtamercolak@gmail.com ORCID: orcid.org/0000-0003-3844-4785

Received/Geliş Tarihi: 26.06.2019 Accepted/Kabul Tarihi: 23.01.2020

${ }^{\oplus}$ Copyright 2020 by Turkish Neurological Society

Turkish Journal of Neurology published by Galenos Publishing House. 


\section{Introduction}

According to the World Health Organization, stroke is a clinical picture characterized by rapid development of symptoms of loss of brain function without any cause other than vascular causes (1). It is the third greatest cause of death in the world, especially in the United States and Western countries, after coronary artery diseases and cancers. It is also a social and economic problem because the majority of patients who survive stroke need constant help to sustain their lives $(2,3)$. When we look at stroke types, the American Stroke Association states that $87 \%$ of patients have ischemic stroke (IS) and $13 \%$ have hemorrhagic stroke (HS) (4). When we look at the risk factors that contribute to the development of acute stroke, they are divided into modifiable and non-modifiable factors. Hypertension, hyperlipidemia, coronary artery disease, and Diabetes mellitus are modifiable factors, and age, sex, and race are non-modifiable risk factors (5). Many studies in the literature have shown that seasonal changes have an effect on stroke incidence and mortality and morbidity $(6,7)$.

In patients with IS, different neurologic presentations may develop due to impaired cerebral blood flow and consequent loss of function of the affected brain region. In a detailed bedside neurologic examination, it may be possible to estimate the location, extent and prognosis of the infarction by evaluating some basic findings. The classification used in the Oxfordshire Community Stroke Project study included small and large infarctions in the territory of anterior carotid artery, partial anterior circulation infarction, total anterior circulation infarction (TACI), posterior (vertebrobasilary arteries) circulation infarction (POCI), and lacunar infarction (LACI) (8).

Although the mortality-morbidity rates of acute stroke are very high in our country, the number of adequate studies on patients with stroke is limited. With this study, we aimed to investigate the etiologic, demographic, and clinical characteristics of patients admitted to our emergency department with acute stroke, and to contribute to stroke data in our region and country.

\section{Materials and Methods}

After our study was approved by the Ethics Committee of Bolu Abant İzzet Baysal University, Faculty of Medicine, data of adult patients aged 18 years or older who were diagnosed as having acute stroke in the emergency department of our hospital between January 1st, 2017, and December 31 st, 2018, were examined. In order to access the data of the patients admitted to the emergency department due to acute IS and HS, the protocol numbers of patients who received IS and HS diagnosis codes according to the ICD-10 diagnostic coding system were taken from the hospital automation system. With the protocol numbers obtained, the patient's files were accessed from our hospital archive. Patients diagnosed as having IS and HS with radiologic imaging were included in the study. Patients diagnosed as having subarachnoid hemorrhage, epiduralsubdural hemorrhage, and transient ischemic attack were excluded from the study. The patients with IS were divided into three groups: ACI, POCI, and LACI according to their clinical and radiologic characteristics. Patients with HS were grouped as basal ganglia, lobar, thalamic, brainstem, and cerebellar hemorrhages according to the localization of the hemorrhagein imaging. The clinical and demographic characteristics of the patients were recorded through the hospital's automation system.

A standard data collection form was created for our study. The patient's age, sex, time of admission, symptom, accompanying risk factors, time of imaging, duration of hospitalization, blood pressure (BP) value at the time of admission, and prognosis were recorded on the patient form. The resulting data were grouped for analysis. Three groups were created by admission time: 08:0016:00, 16:00-24:00, and 24:00-08:00. According to the admission season, four groups were created: spring, summer, autumn, and winter. Two groups were created according to the time of transportation from symptom onset to the hospital including patients who arrived at hospital before 4.5 hours and those who arrived after 4.5 hours. Patients were divided into three groups as hypotensive (systolic BP $<90 \mathrm{~mm} \mathrm{Hg}$, diastolic BP $<60 \mathrm{mmHg}$ ), normotensive (systolic BP: 90-140 mm Hg, diastolic BP: 60-90 $\mathrm{mm} \mathrm{Hg}$ ) and hypertensive (systolic BP $>140 \mathrm{~mm} \mathrm{Hg}$, diastolic BP $>90 \mathrm{~mm} \mathrm{Hg}$ ) according to the BP value at the time of admission.

\section{Statistical Analysis}

For descriptive statistics, median (minimum - maximum) values are given for numeric variables that did not have normal distribution. For categorical variables, number (n) and $\%$ (percentage) values are given. The differences between etiologic, demographic, and clinical characteristics between the hemorrhagic and IS groups were compared using the MannWhitney U test for numeric variables. Pearson's chi-square test or Fisher's exact chi-square test was used to compare categorical variables. Multiple logistic regression analyses were performed to assess independent risk factors of mortality after stroke and odds ratios and 95\% confidence intervals were calculated for each risk factor after controlling for theeffects of other variables. $\mathrm{P}<0.05$ was accepted as the level of statistical significance in all tests. Statistical analysis of the data was performedusing the Statistical Package for the Social Sciences (SPSS) for Windows 21.0 package program.

\section{Results}

Our study was completed with 236 patients who were admitted to the emergency department over a two-year period, whose data could be accessed. Of the patients, $210(88.9 \%)$ were diagnosed as having IS and 26 as having HS (11.1\%). The median age of patients with IS was 73 (range, 25-92) years, and the median age of patients with HS was 74.5 (range, 34-90) years. By sex, 129 $(54.7 \%)$ patients were male and $107(45.3 \%)$ were female. Of the patients who had IS, $117(55.7 \%)$ were male, and $14(53.8 \%)$ patients who had HS were female. From the onset of symptoms to the time of hospital admission, $106(44.9 \%)$ patients arrived within the first 4.5 hours, and $130(55.1 \%)$ patients arrivedafter 4.5 hours. Within the first 4.5 hours, $90(42.9 \%)$ patients with IS were admitted to the hospital emergency department. Of these patients, $32(36 \%)$ who were eligible received thrombolytic therapy. According to the $\mathrm{BP}$ values of the patients at the time of admission, $130(55.1 \%)$ patients were hypertensive, and 8 $(3.4 \%)$ patients were hypotensive. One hundred nine $(51.9 \%)$ patients with IS were hypertensive and $21(80.8 \%)$ with HS were 
hypertensive. Of the patients, $148(62.7 \%)$ were admitted to the ward, and $88(37.3 \%)$ were admitted to the intensive care unit (ICU). Sixty-eight $(32.4 \%)$ patients with IS were admitted to the ICU, and 20 (76.9\%) patients with HS were admitted to ICU. The HS and IS groups were statistically significantly different in terms of BP values $(\mathrm{p}=0.003)$ and hospitalization services $(\mathrm{p}<0.001)$. The mean duration of hospitalization of patients with IS was 7 (range, 1-240) days, whereasit was 10 (range 3-70) days in the HS group $(\mathrm{p}=0.019)$. Two hundred five $(86.9 \%)$ patients were discharged from the hospital, and $31(13.1 \%)$ patients died $(\mathrm{p}=0.002)$ (Table 1).

When examined according to the symptomsof the patients, $150(63.6 \%)$ of 236 patients had unilateral muscle weakness, which was the most common cause of admission, and speech impairment was the second most common cause of admission. Of the patients with IS, $140(66.7 \%)$ had unilateral muscle weakness and $110(47.6 \%)$ had speech impairment, and $10(38.5 \%)$ patients had unilateral muscle weakness and 17 (65.4\%) had speech impairment in the HS group. There was a statistically significant difference in terms of having unilateral muscle weakness between the two groups $(\mathrm{p}=0.005)$ (Table 2$)$.

In our study, when the risk factors of the patients were examined, $163(69.1 \%)$ patients had hypertension, $99(41.9 \%)$ patients smoked, and $74(31.4 \%)$ patients had Diabetes mellitus. Hypertension was the most common risk factor in patients with IS and HS, followed by smoking (Table 3).

\begin{tabular}{|c|c|c|c|c|}
\hline & $\begin{array}{l}\text { Total } \\
\mathrm{n}(\%)\end{array}$ & $\begin{array}{l}\text { Ischemic stroke } \\
\text { n }(\%)\end{array}$ & $\begin{array}{l}\text { Hemorrhagic stroke } \\
\mathrm{n}(\%)\end{array}$ & $\mathrm{p}$ \\
\hline \multicolumn{5}{|l|}{ Sex } \\
\hline Female & $107(45.3)$ & $93(44.3)$ & $14(53.8)$ & 0.356 \\
\hline$<4.5$ hours & $106(44.9)$ & $90(42.9)$ & $16(61.5)$ & \multirow{2}{*}{0.071} \\
\hline$>4.5$ hours & $130(55.1)$ & $120(57.1)$ & $10(38.5)$ & \\
\hline \multicolumn{5}{|l|}{ Blood pressure } \\
\hline Hypertensive & $130(55.1)$ & $109(51.9)$ & $21(80.8)$ & 0.003 \\
\hline Ward & $148(62.7)$ & $142(67.6)$ & $6(23.1)$ & \multirow{2}{*}{$<0.001$} \\
\hline Intensive care unit & $88(37.3)$ & $68(32.4)$ & $20(76.9)$ & \\
\hline Duration of hospitalization (day) & $7(1-240)$ & $7(1-240)$ & $10(3-70)$ & 0.019 \\
\hline \multicolumn{5}{|l|}{ Outcome } \\
\hline Discharged & $205(86.9)$ & $188(89.5)$ & $17(65.4)$ & \multirow{2}{*}{0.002} \\
\hline Death & 31 (13.1) & $22(10.5)$ & $9(34.6)$ & \\
\hline n: Number & & & & \\
\hline
\end{tabular}

Table 2. The relationship between patient symptomsand stroke groups

\begin{tabular}{|lllll} 
& $\begin{array}{l}\text { Total } \\
\mathbf{n}(\%)\end{array}$ & $\begin{array}{l}\text { Ischemic stroke } \\
\mathbf{n}(\%)\end{array}$ & $\begin{array}{l}\text { Hemorrhagic stroke } \\
\mathbf{n}(\%)\end{array}$ & $10(38.5)$ \\
Unilateral muscle weakness & $150(63.6)$ & $140(66.7)$ & $17(65.4)$ & 0.005 \\
Speech impairment & $119(50.4)$ & $110(47.6)$ & $13(50.0)$ & 0.087 \\
Loss of consciousness & $67(28.4)$ & $54(25.7)$ & $1(3.8)$ & 0.010 \\
Epileptic seizure & $7(3.0)$ & $6(2.9)$ & $2(7.7)$ & 0.779 \\
Vertigo & $26(11.0)$ & $24(11.4)$ & $6(23.1)$ & $2(7.7)$ \\
Headache & $12(5.1)$ & $6(2.9)$ & & 0.566 \\
Visual impairment & $9(3.8)$ & $7(3.3)$ & & \\
n: Number & & & \\
\hline
\end{tabular}


According to the magnetic resonance diffusion-weighted imaging findings, $143(68 \%)$ patients had ACI, 41 (19.5\%) had POCI, and $24(11 \%)$ had LACI. Two (1\%) patients had ACI + POCI. Of the patients who died, $65.3 \%$ were in the ACI group and $26.1 \%$ were in the POCI group. One $(4.3 \%)$ of the patients in the LACI group died, and one of the two patients with ACI + POCI died.

The relationship between the risk factors for acute stroke with the risk of death was examined usiing multiple logistic regression analysis. The mortality odds ratio was 3.18 (95\% CI: 1.349-7.498; $\mathrm{p}=0.008)$ times higher in patients with atrial fibrillation when other factors were controlled. Furthermore, the mortality odds ratio of patients with HS was 4.29 times higher (95\% CI: 1.57911.647; $\mathrm{p}=0.004$ ) than in those with IS (Table 4).

According to the hospital admission hours of the patients, $110(46.6 \%)$ patients were admitted between 16:00 and 24:00, and $28(11.9 \%)$ patients were admitted between 24:00 and
08:00. The distribution of patients according to admission hours is presented in Chart 1. According to the hospital admission months of the patients, $6.7 \%$ of the patients with IS were admitted in June, $10 \%$ in July, and $11.4 \%$ in August; $34.6 \%$ of the patients with HS were admitted in June. The distribution of patients by month is shown in Chart 2. According to the hospital admission seasons of the patients, the most frequent admissions were in the summer months with a rate of $29.7 \%$. Of the 26 patients who had HS, $11(42.3 \%)$ were admitted in the summer. The distribution of patients by season is shown in Chart 3.

\section{Discussion}

When we look at the causes of death in our country, strokerelated deaths come in second place after cardiovascular diseaserelated deaths. Due to dependency, disability, and labor loss in surviving patients, both individual and social material-spiritual Table 3 . The relationship between risk factors and stroke groups

\begin{tabular}{|lllll} 
& $\begin{array}{l}\text { Total } \\
\mathbf{n}(\%)\end{array}$ & $\begin{array}{l}\text { Ischemic stroke } \\
\mathbf{n}(\%)\end{array}$ & $\begin{array}{l}\text { Hemorrhagic stroke } \\
\mathbf{n}(\%)\end{array}$ & $20(76.9)$ \\
Hypertension & $163(69.1)$ & $143(68.1)$ & $4(15.4)$ & 0.358 \\
Diabetes & $74(31.4)$ & $70(33.3)$ & $3(11.5)$ & 0.063 \\
Hyperlipidemia & $16(6.8)$ & $13(6.2)$ & $12(46.2)$ & 0.306 \\
Smoking & $99(41.9)$ & $87(41.4)$ & $9(34.6)$ & 0.645 \\
Coronary artery disease & $76(32.2)$ & $67(31.9)$ & $10(38.5)$ & 0.780 \\
History of a stroke & $72(30.5)$ & $62(29.5)$ & $8(30.8)$ & 0.350 \\
Atrial fibrillation & $50(21.2)$ & $42(20.0)$ & & 0.205 \\
n: Number & & & \\
\hline
\end{tabular}

Table 4 . The risk factors of mortality after stroke in patients admitted to hospital

\begin{tabular}{|c|c|c|}
\hline Risk Factors & Odds ratio $(95 \% \mathrm{CI})$ & $\mathrm{p}$ \\
\hline Age & $1.013(0.979-1.048)$ & 0.462 \\
\hline Sex, male & $1.324(0.488-3.911)$ & 0.612 \\
\hline Hypertension & $1.109(0.414-2.972)$ & 0.837 \\
\hline Diabetes & $1.008(0.391-2.599)$ & 0.986 \\
\hline Smoking & $0.758(0.240-2.389)$ & 0.636 \\
\hline $\begin{array}{l}\text { Coronary artery } \\
\text { disease }\end{array}$ & $0.440(0.167-1.162)$ & 0.098 \\
\hline History of stroke & $1.265(0.532-3.007)$ & 0.594 \\
\hline Atrial fibrillation & $3.181(1.349-7.498)$ & 0.008 \\
\hline $\begin{array}{l}\text { Admission time, } \\
<4.5 \text { hours }\end{array}$ & $1.712(0.730-4.016)$ & 0.216 \\
\hline $\begin{array}{l}\text { Diagnosis, } \\
\text { hemorrhagic stroke }\end{array}$ & $4.289(1.579-11.647)$ & 0.004 \\
\hline \multicolumn{3}{|c|}{$\begin{array}{l}\text { The goodness of fit of the multiple logistic regression model was confirmed } \\
\text { using the Hosmer-Lemeshow test ( } \mathrm{p}=0.399) \text {, CI: Confidence interval } \\
\text { Significant } \mathrm{p} \text { values are shown in bold. }\end{array}$} \\
\hline
\end{tabular}

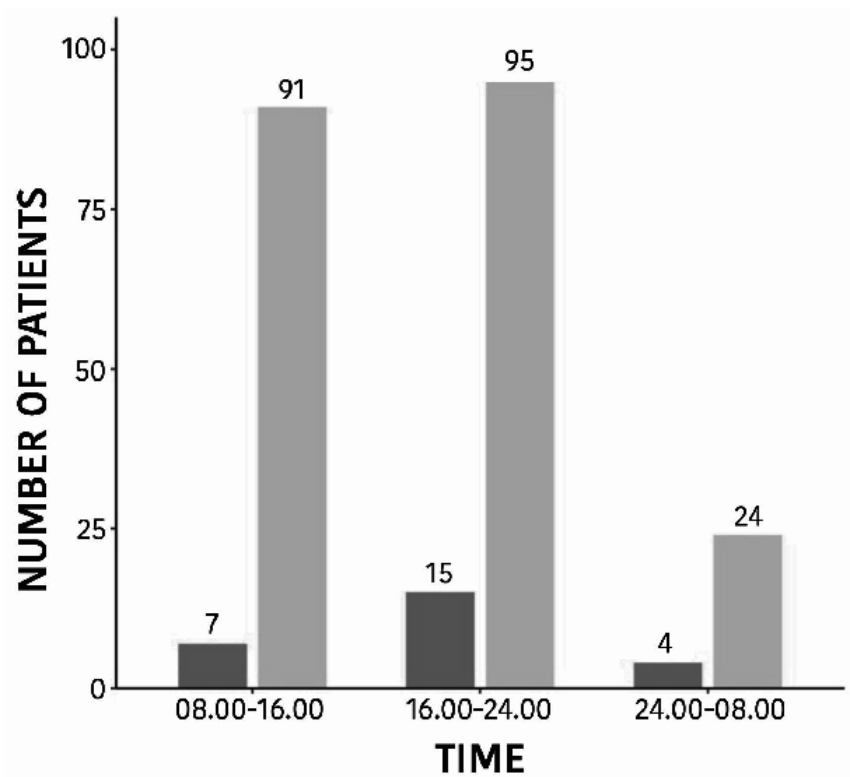

DIAGNOSIS Hemorrhagic stroke Ischemic stroke

Chart 1. Distribution of stroke patients by time of admission 


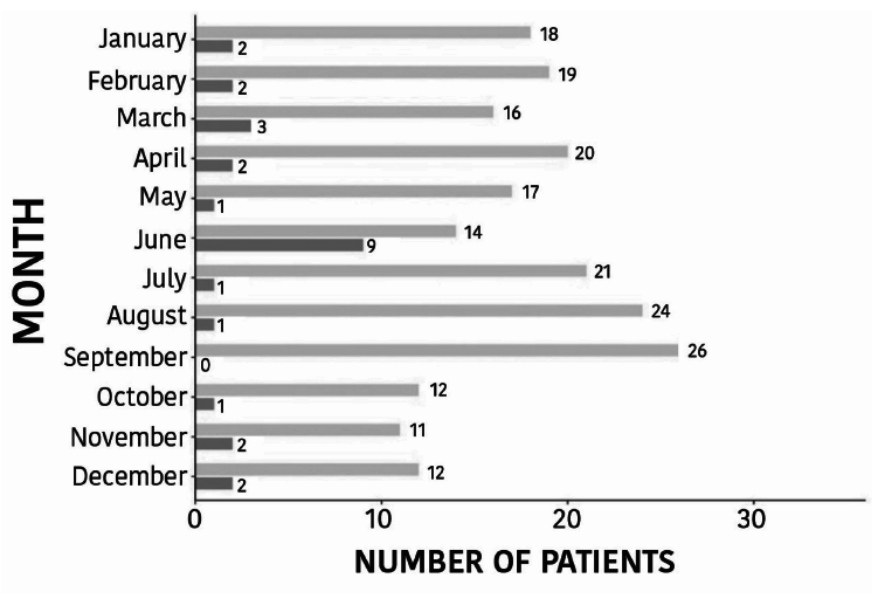

DIAGNOSIS — Hemorrhagic stroke $\square$ Ischemic stroke

Chart 2. Distribution of stroke patients by month of admission

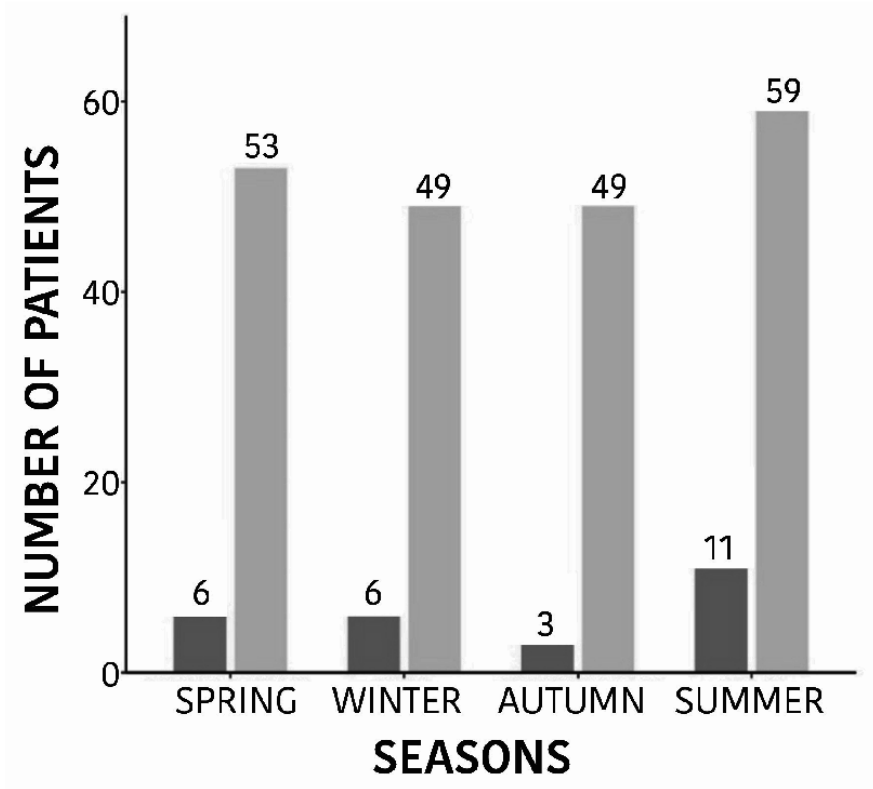

DIAGNOSIS — Hemorrhagic stroke — Ischemic stroke

Chart 3. Distribution of stroke patients by session of admission

problems arise (9). Although there are non-modifiable risk factors in the development of the disease, the frequency of the disease can be reduced by reducing modifiable factors. Therefore, epidemiologic research on stroke causes will help to identify the priorities in the health policy of society.

One of the most important risk factors of stroke is age. In studies, it was determined that $70 \%$ of hospitalized patients with stroke were aged 65 years or older $(7,10)$. The median age of the patients in our study was 73 years ( 73 years in patients with IS and 74.5 years in patients with HS). These values show that older age is an important risk factor in patients with stroke. In the literature, it was found that the frequency of stroke with increased age increased in men compared with women, and the incidence of stroke in men between the ages of 55-65 years was twice as high as in women (3, 11). Similar to the literature, the incidence of stroke in men was found to be higher than in women in our study.

The aim of intravenous thrombolytic therapy in patients with IS is to ensure continuity of blood flow to the brain with the dissolution of the thrombus. In the studies and published guidelines, thrombolytic therapy can be given within the first 4.5 hours, but only $21-48 \%$ of patients are admitted to the hospital during this period, and it is emphasized that this rate should be increased $(12,13)$. Although the delay in admission of patients with acute stroke to the emergency department develops at different stages, the greatest time lost is in the pre-hospital period (14). Kiyan et al. (3) found that the most important factor causing delay in the pre-hospital period was the length of time takenin seeking medical assistance. Mosley et al. (15) found that the time from the onset of stroke symptoms to the calling of an ambulance accounted for the largest proportion of prehospital delay. The most important factors in the delay of admission to the hospital are listed in order of not knowing the symptoms of stroke, not being aware of the severity of the disease, ignoring the disease, symptoms starting during night hours, and the expectation that the symptomswill recover spontaneously (16). Our study found that $42.9 \%$ of patients with IS were admitted to our hospital within the first 4.5 hours. Having advanced age, comorbid diseases, living in rural areas of our province, and having the idea that the symptomswill go away on their own were the reasons of delayed emergency admission times. We believe that by informing people using today's mass media, explaining to society that stroke is a disease that has a treatment, admission times can be significantly shortened.

Ünivar et al. (17) showed that cardiovascular diseases were the leading causes of death in Turkey with $21.7 \%$, followed by stroke with $15 \%$. One-third of patients who were followed up due to stroke lost their lives and one-third were in need of care. The mortality rate in patients with IS was found to be higher than in patients with HS, but the reason for this was not explained in the study by Altun et al. (7). Çı̆gşar and User (18) found that the mortality rate was $42.9 \%$ in HS, whereas it was $6.2 \%$ in IS. Türkel et al. (19) evaluated 6-month mortality in IS and they found that the mortality rate was 33\%.In our study, $13.1 \%$ of the patients who were followed up died. The mortality rates of patients with IS and HS were $10.5 \%$ and $34.6 \%$, respectively. Short-term mortality rates were higher in patients with IS than in similar studies in the literature. The average age of the patients enrolled in our study was higher than in these other studies. The literature indicated that TACI was the group with the worst prognosis and resulted in the most severe disability among stroke groups (13). In our study, $65.3 \%$ of the patients who died had ACI, and one (4.3\%) patient with ACI + POCI coexistence died. We believe that advanced age and having ACI were the main factors affecting mortality in patients with IS. The long-term prognosis of patients was not evaluated in this study. Therefore, more comprehensive studies are needed in our region. 
In this study, the most common symptomsof patients were, listed in order, unilateral muscle weakness, speech impairment, and loss of consciousness. Loss of consciousness was observed in $50 \%$ of patients with HS. In the literature, hemiplegia and hemiparesis were reported as the most common neurologic examination findings in patients with acute stroke $(18,20)$. Our findings were similar to the literature and we believe that loss of consciousness was among the most common findings in patients with HS.

The risk factors of acute stroke in our study were, listed in order, hypertension, smoking, coronary artery disease, and Diabetes mellitus. Of the patients, $41.9 \%$ were smokers. Studies have shown that the most common risk factors are hypertension, diabetes, and hyperlipidemia $(3,21)$. Similar results were found in studies conducted in the Middle East and Asian countries (22). We believe that smoking is a leading cause of stroke among the modifiable risk factors. İnanç et al. (23) showed that the mortality rate was $15.9 \%$ in patients with HS and $1.9 \%$ in patients with IS. In our study, we found that the mortality rate was 4.29 times higher in patients with HS than in patients with IS. Furthermore, we found that atrial fibrillation was an independent risk factor for mortality in patients with acute stroke and that atrial fibrillation increased the mortality risk by 3.18 times; we concluded that this group of patients should be monitored more closely.

In the literature, the effect of seasonal changes on stroke incidence has been reported in many studies $(24,25)$. İnanç et al. (23) found that $29.5 \%$ of admissions for IS were in the summer and $44.3 \%$ of admissions for HS were in winter (22). Anlar et al. (26) found that IS and HS were more common in summer. In our study, the incidences of IS and HS were higher in summer than in other seasons, and the incidence of both stroke groups was significantly lower in autumn. It was particularly remarkable that $34.6 \%$ of patients with HS were admitted in June in our study. We believe that different results in studies may be the result of genetic differences as well as factors such as regional climate changes, air humidity, pressure, and temperature. In the Western Black Sea region and Bolu Province where our clinic serves, heat differences between the summer and winter seasons are clearly felt. The fact that warm weather triggers hypertension suggests that HS are more common in the summer months. We believe that during periods of increased air temperature, stroke rates will decrease by not being exposed to direct sunlight and protecting patients from hot air.

Being a study conducted in one center, the failure to elaborate stroke subtypes and absence of evaluation of long-term patient prognosis are the main limitations of our study.

\section{Conclusion}

We found that non-modifiable risk factors of acute stroke such as age and sex detected in Bolu in our study were similar to different societies, and that seasonal changes might be risk factors for IS and HS. In addition, the early arrival of patients to the emergency department and the removal of risk factors such as smoking would contribute to the reduction of both mortality and morbidity rates.

\section{Ethics}

Ethics Committee Approval: The study was approved by Bolu Abant Izzet Baysal University Clinical Research Ethics Committee (protocol no: 2019/26).

Informed Consent: Informed consent form was obtained from all patients included in our study.

Peer-review: Externally and internally peer-reviewed.

\section{Authorship Contributions}

Surgical and Medical Application: T.Ç., H.İ.Y., K.Ç., Concept: T.Ç., B.Ö.T., O.K., Design: T.Ç., H.İ.Y., K.Ç., Data Collection or Processing: T.Ç., H.İ.Y., K.Ç., B.Ö.T., Analysis or Interpretation: T.Ç., O.K., Literature Search: T.Ç., H.İ.Y., K.Ç., Writing: T.Ç.

Conflict of Interest: The authors have not reported any conflicts of interest in relation to this article.

Financial Support: No financial support has been received from any institution or person for our work.

\section{References}

1. Alagöz A.N., Öztürk Ş., Özbakır Ş. Akut İskemik İnmede İnflamasyon Göstergesi Olarak Akut Faz Reaktanları. Boğaziçi Tıp Dergisi 2018;5:8491.

2. Benjamin EJ, Muntner P, Bittencourt MS, et al. Heart disease and stroke statistics-2019 update: a report from the American Heart Association. Circulation 2019; 39:e56-e528.

3. Kıyan S, Özsaraç M, Ersel M, et al. Acil Servise Başvuran Akut İskemik İnmeli 124 Hastanın Geriye Yönelik Bir Yıllık İncelemesi. Akademik Acil Tip Dergisi 2009;8:15-20.

4. Fisher M. Stroke and TIA: Epidemiology, Risk Factors, and the Need for Early Intervention. Am J Manag Care 2008;14:204-211.

5. Olcay HÖ, Çevik Y, Emektar E. Akut İskemik İnme Geçiren Hastalarda Radyolojik Görüntüleme Bulguları ve Bu Bulgulara Etki Eden Faktörlerin Değerlendirilmesi. Ankara Medical Journal 2018;18:492-499.

6. Kabakcı G, Abacı A, Ertaş FS, Özerkan F, Erol Ç, Oto A. "Türkiye'de hipertansif hastalarda inme riski ve inme riski açısından bölgesel farklılıkların belirlenmesi: Hastane tabanl, kesitsel, epidemiyolojik anket (THINK)* çalışması." Türk Kardiyoloji Derneği Arşivi 2006;34:395-405.

7. Altun Y, Aydın İ, Algın A. Adıyaman İlinde İnme Tiplerinin Demografik Özellikleri. Turk Noroloji Dergisi 2018;24:26-31.

8. Yang Y, Wang A, Zhao X, et al. The Oxfordshire Community Stroke Project classification system predicts clinical outcomes following intravenous thrombolysis: a prospective cohort study. Therapeutics and clinical risk management 2016;12:1049-1056.

9. Ozturk S. Epidemiology and the Global Burden of Stroke-Situation in Turkey. World neurosurgery 2014;81:35-36.

10. Soyuer F, Ünalan D, Öztürk A. İnme hastalarında yaş ve cinsiyetin fonksiyonel yetersizlik üzerine olan etkisi. İnönü Üniversitesi Tip Fakültesi Dergisi 2007;14:91-94.

11. Kumral E, Balkır K. İnme epidemiyolojisi. Balkan S (eds). Serebrovasküler Hastalıklar. Ankara, Güneş Kitabevi; 2002. p. 38-40.

12. Michaels AD, Spinler SA, Leeper B, et al. Medication errors in acute cardiovascular and stroke patients: a scientific statement from the American Heart Assocition. Circulation 2010;121:1664-1682.

13. Çetiner M, Kabay SC, Aydın HE. Akut İskemik İnmede İntravenöz Trombolitik Tedavi: Kütahya Deneyimleri. Türk Nöroloji Dergisi 2017;23:193-198.

14. Evenson KR, Rosamond WD, Morris DL. Prehospital and in-hospital delays in acute stroke care. Neuroepidemiology. 2001;20:65-76.

15. Mosley I, Nicol M, Donnan G, Patrick I, Kerr F, Dewey H. The impact of ambulance practice on acute stroke care. Stroke 2007;38:2765-2770.

16. European Stroke Organisation (ESO) Executive Committee; ESO Writing Committee. Guidelines for management of ischaemic stroke and transient ischaemic attack 2008. Cerebrovasc Dis 2008;25:457-507. 
17. Ünivar N, Mollahaliloğlu S, Yardım N (eds). Türkiye hastalık yükü Çalışmas 2004. Ankara RSHMB: Hifzısıhha Mektebi Müdürlüğü, Sağglık Bakanlığı, Aydoğdu Ofset Matbaacilık; 2007;24-31.

18. Çığşar G, User NN. Acil servise başvuran akut inmeli hastaların analizi. Kafkas J Med Sci 2015;5:6-12.

19. Türkel Y, Güngör L, Onar MK. The Predictors of Mortality, Recurrence and Functional Recovery in Ischemic Cerebrovascular Disease. Turk Norol Derg 2010;16:177-186.

20. Fatema K, Bailey KR, Petty GW, et al. Increased left atrial volume index: potent biomarker for first-ever ischemic stroke. Mayo Clin Proc 2008;83:1107-1115.

21. Hakbilir O, Çete Y, Göksu E, Akyol C, Kılıçaslan İ. İnme popülasyonun demografik özellikleri ve geç acil servis başvurularının yeni tedavi yaklaşımları üzerine etkisi. Turk J Emerg Med 2006;6:132-138.
22. Suzuki K, Kutsuzava T, Takita K et al. Clinico-epidemiologic Study of Stroke in Akita, Japan. Stroke 1987;18:402-06.

23. İnanç $Y, A y H$, İnanç $Y$, et al. Şanlıurfa ilinde inme tiplerinin demografik özellikleri. J Clin Anal Med 2015;6(Suppl 3):257-260.

24. Shinkawa A, Ueda K, Hasuo Y, Kiyohara Y, Fujishima M. Seasonal variation in stroke incidence in Hisayama, Japan. Stroke 1990;21:1262-1267.

25. Slatina E, Music M, Babic N, et al. Correlation Between Change in Air Humidity and the Incidence of Stroke. Mater Sociomed 2013;25:242-245.

26. Anlar O, Tombul T, Unal O, Kayan M. Seasonal and environmental temperature variation in the occurrence of ischemic strokes and intracerebral hemorrhages in a Turkish adult population. Int J Neurosci 2002;112:959963. 